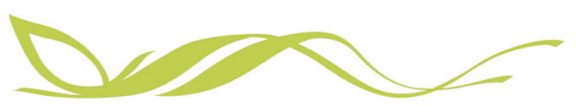

COMMUNICATIONS

ARTICLE

\author{
https://doi.org/10.1038/s43247-020-00063-w OPEN
}

\title{
Exceptional warmth and climate instability occurred in the European Alps during the Last Interglacial period
}

Paul S. Wilcox (1) ${ }^{1 凶}$, Charlotte Honiat ${ }^{1}$, Martin Trüssel $^{2}$, R. Lawrence Edwards ${ }^{3}$ \& Christoph Spötl (i] ${ }^{1}$

Warmer temperatures than today, over a period spanning millennia, most recently occurred in the Last Interglacial period, about 129,000 to 116,000 years ago. Yet, the timing and magnitude of warmth during this time interval are uncertain. Here we present a reconstruction of temperatures in the Swiss Alps over the full duration of the Last Interglacial period based on hydrogen isotopes from fluid inclusions in precisely dated speleothems. We find that temperatures were up to $4.3^{\circ} \mathrm{C}$ warmer during the Last Interglacial period than in our present-day reference period 1971 to 1990 . Climate instability, including an abrupt cooling event about 125,500 years ago, interrupted this thermal optimum but temperatures remained up to $2.0^{\circ} \mathrm{C}$ warmer than the present day. We suggest that higher-elevation areas may be more susceptible to warming relative to lowland areas, and that this may hold also for a future climate forced by increasing levels of greenhouse gases.

\footnotetext{
${ }^{1}$ Institute of Geology, University of Innsbruck, 6020 Innsbruck, Austria. ${ }^{2}$ Foundation Naturerbe Karst und Höhlen Obwalden (NeKO), 6055

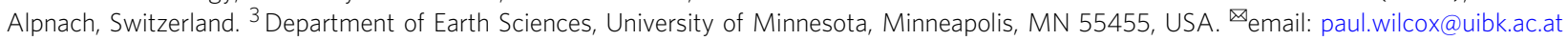


$\mathrm{T}$ he Last Interglacial period (LIG), roughly equivalent to Marine Isotope Stage (MIS) 5e, 129-116 thousand years ago (ka), is currently the focus of increased interest as it provides a potential test bed for warmer conditions on Earth. In central Europe, previous work has found that summer temperatures may have been about $1-2{ }^{\circ} \mathrm{C}$ warmer than present during the optimum ${ }^{1-4}$, with alpine regions possibly experiencing warmer temperatures of $+4.3 \pm 1.6^{\circ} \mathrm{C}^{5}$. Additionally, it is becoming more widely accepted that millennial- to centennial-scale swings in climate were intrinsic to this time period ${ }^{6,7}$. However, the magnitude, as well as the timing and spatial variability of climate during this period are still widely debated. This is largely due to the paucity of independently dated records that cover the entire LIG, with even fewer records having the necessary resolution to capture subtle climate oscillations. Because of this, quantitative temperature reconstructions are rare. The few available temperature reconstructions are from biogenic archives $6,8,9$, leading to potential biases. Further, a critical lack of age control for biogenic proxies has led to reported temperature fluctuations being poorly constrained in time. To address this, we reconstruct temperatures using fluid inclusions extracted from precisely dated speleothems. Fluid inclusions (fi), which are natural repositories of precipitation falling above the cave, are reliable indicators of paleotemperature ${ }^{10-13}$. The measurement of hydrogen isotopes $\left(\delta D_{f}\right)$ in speleothem fluid inclusion water can be performed with high precision ${ }^{14,15}$, allowing robust paleotemperatures to be calculated. Here, we provide a centennial to millennial-scale temperature reconstruction (dubbed SKR-FIT for Schrattenkarst fluid inclusion temperature) using $\delta \mathrm{D}_{\mathrm{fi}}$ fluid inclusion data from speleothems collected from two subalpine caves in Switzerland (Fig. 1). The SKR-FIT record indicates temperatures up $4.3 \pm 1.4^{\circ}$ C higher than modern-day (1971-1990) during the LIG and a $1.9 \pm 1.4^{\circ} \mathrm{C}$ decrease over this thermal maximum.

Site setting. The caves are located on Schrattenkarst in the Melchsee-Frutt region of central Switzerland $\left(46^{\circ} 47^{\prime} \mathrm{N}, 8^{\circ} 16^{\prime} \mathrm{E}\right)$ (Fig. 1 and Supplementary Fig. 1), a karst region characterized by a high density of caves with a cumulative length of $65 \mathrm{~km}$. The caves developed in different paleo-phreatic levels between 1300 and $2450 \mathrm{~m}$ above sea level (a.s.l. ${ }^{16}$. The host rocks are limestones (Quinten Formation) and limestone-marl successions (Mürtschen Member of the Schilt Formation ${ }^{17}$ ) of uppermost Jurassic to lowermost Cretaceous age. Speleothems from two caves close in proximity, Neotektonik Cave and Schratten Cave, were studied. The former opens at $1727 \mathrm{~m}$ a.s.l. and comprises $2.1 \mathrm{~km}$ of galleries; the latter is much larger $(19.7 \mathrm{~km})$ and its entrance is located at $1716 \mathrm{~m}$ a.s. ${ }^{18}$. Three stalagmites (M37-116A, M37-1-16C, M37-1-23A), found broken and inactive, were collected $75-103 \mathrm{~m}$ behind and $27 \mathrm{~m}$ below the entrance of Neotektonik Cave where the rock overburden is $30-35 \mathrm{~m}$. One stalagmite (M6-73-3) was found in Schratten Cave $475 \mathrm{~m}$ behind and $136 \mathrm{~m}$ below the entrance where the rock overburden reaches $54 \mathrm{~m}$. The catchment of the cave is located at the transition from the subalpine zone with a few scattered stands of spruce to alpine grasslands. The natural tree-line in this area is located at about $1900 \mathrm{~m}$ a.s.l., but mostly lower due to century-long pasturing. The catchment is partly covered by thin, brown soil and partly barren karstified rock. The mean annual air temperature at the elevation of the cave is $2.9^{\circ} \mathrm{C}$ based on data from nearby meteorological stations (1990-2018; see "Methods" section). Mean annual precipitation at the study site is $\sim 2200 \mathrm{~mm}$.

\section{Results}

The four speleothems (M37-1-16A, M37-1-16C, M6-73-3, and M37-1-23A) represent a stacked record, with a combined $\sim 19$ ka

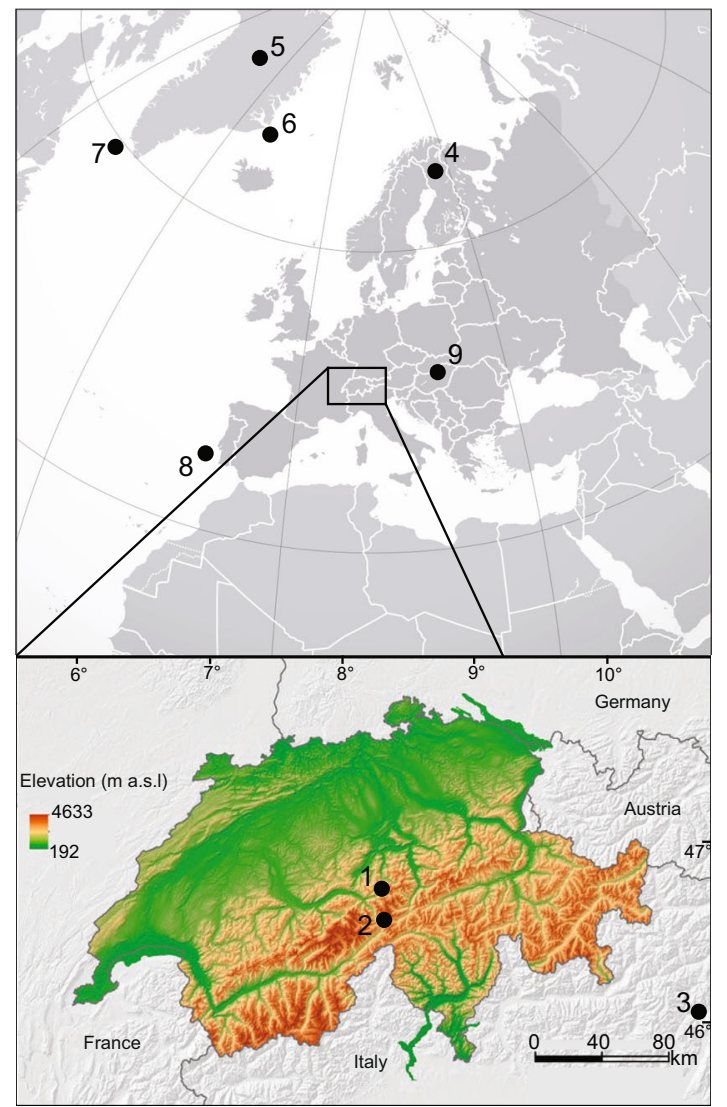

Fig. 1 Locations of sites discussed in the text. 1. Schrattenkarst caves (this study); 2. Grimsel Pass; 3. Cesare Battisti Cave ${ }^{5}$; 4 . Sokli sequence ${ }^{6} ;$. NGRIP28; 6. Core M2335122; 7. Core MD03-266423,24 8. Core MD95204229; 9. Baradla Cave ${ }^{26}$. Source of elevation profile: Federal Office of Topography swisstopo.

years of growth between $132.0 \pm 0.5$ and $112.0 \pm 0.5 \mathrm{ka}$, and a $\sim 700$-year hiatus between $128.0 \pm 1.7$ and $127.3 \pm 0.7 \mathrm{ka}$ (Fig. 2 and Supplementary Data 1). Additional hiatuses were identified between $127.3 \pm 0.7$ and $125.6 \pm 0.5 \mathrm{ka}$, and between $126.0 \pm 0.6$ and $125.6 \pm 0.5 \mathrm{ka}$ in M37-1-16A and M37-1-16C, respectively (Fig. 2). These additional hiatuses were likely the result of drip water switching between speleothems M37-1-16A and M37-116C (which grew side by side). All speleothems show consistent oxygen and carbon isotope values, except for speleothem M6-733 , which shows a lower slope in the carbon isotope trend (Fig. 2). This is likely due to speleothem M6-73-3 being retrieved from Schratten Cave rather than Neotektonik Cave, with slightly different soil cover properties possibly resulting in slightly different carbon isotope values. Fluid inclusions were obtained from speleothems M37-1-16A, M37-1-16C, M6-73-3, and M37-1-23A (Supplementary Fig. 2 and Supplementary Data 2). The transfer function used to reconstruct paleotemperatures was acquired from the Global Network for Isotopes in Precipitation (GNIP) station at Grimsel Pass $\left(\sim 24 \mathrm{~km}\right.$ from cave site, $0.65 \% /{ }^{\circ} \mathrm{C} \pm 0.05$, $1980 \mathrm{~m}$ a.s.l.) (Fig. 1). Based on our SKR-FIT conversion (Fig. 2 and Supplementary Data 2), temperatures increased rapidly early in the record, between 130.7 and $127.3 \mathrm{ka}$, by $4.6^{\circ} \mathrm{C}$. Afterward, between 127.3 and $125.9 \mathrm{ka}$, temperatures are relatively stable, fluctuating between 5.1 and $6.4^{\circ} \mathrm{C}$. Temperatures then sharply decrease by $1.9^{\circ} \mathrm{C}$ between 125.9 and $125.5 \mathrm{ka}$. Following this drop in temperature, temperatures rise by $1.4^{\circ} \mathrm{C}$ at $125.0 \mathrm{ka}$, but then rapidly decrease again at $124.5 \mathrm{ka}$ by $1.0^{\circ} \mathrm{C}$. Another rise in temperature occurs between 124.5 and $124.6 \mathrm{ka}$, with an increase 


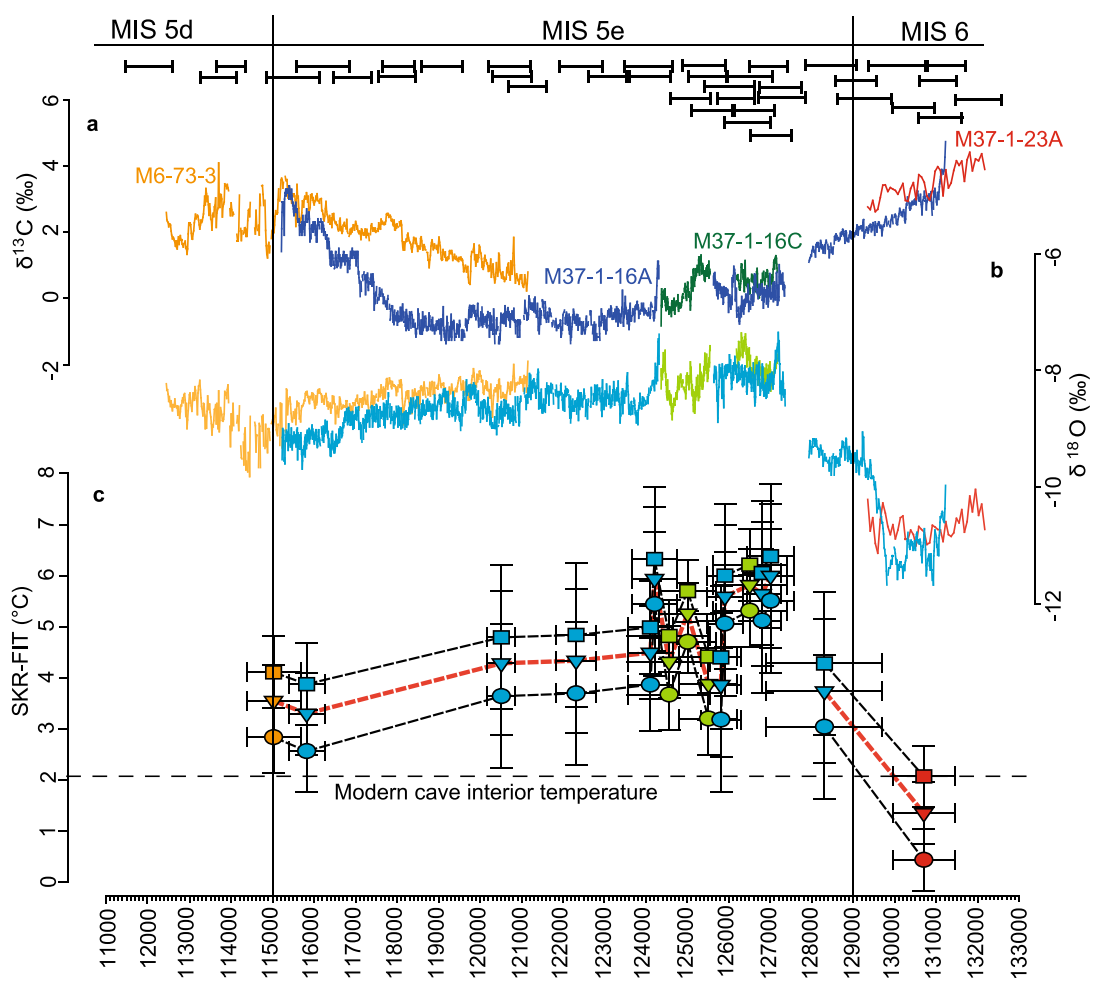

Fig. 2 Schrattenkarst speleothem proxy data. Black error bars above proxy data denote U-Th errors. a $\delta^{13} \mathrm{C}$ values from Schrattenkarst speleothems; b $\delta^{18} \mathrm{O}$ values from Schrattenkarst speleothems; c fluid inclusion temperatures from Schrattenkarst record. Symbols color-coded according to speleothem. Red dashed line is $0.65 \% /{ }^{\circ} \mathrm{C}$ (triangles), while bounding black dashed lines represent $0.6 \% \circ /{ }^{\circ} \mathrm{C}$ (circles) and $0.7 \% \circ /{ }^{\circ} \mathrm{C}$ (squares) transfer functions. Errors represent isotope measurement errors, $\delta^{18} \mathrm{O} /$ annual air temperature slope error, and one standard deviation of repeated measurements.

of $1.6^{\circ} \mathrm{C}$. Afterward, between 124.6 and $124.1 \mathrm{ka}$, temperatures decrease sharply again by $1.4^{\circ} \mathrm{C}$. Temperatures then gradually decrease for the remainder of the record, between 124.1 and 115.0 ka, by $1{ }^{\circ} \mathrm{C}$.

\section{Discussion}

The outstanding features of the SKR-FIT reconstruction are temperatures up to $4.3 \pm 1.4^{\circ} \mathrm{C}$ higher than modern-day (1971-1990) during the LIG and a $1.9 \pm 1.4^{\circ} \mathrm{C}$ decrease over this thermal maximum (Figs. 2 and 3). The warm temperatures corresponding to the LIG thermal maximum occur during two separate time periods, between $127.3 \pm 0.7$ and $125.9 \pm 0.5 \mathrm{ka}$, and between $124.6 \pm 1.0$ and $124.1 \pm 0.5 \mathrm{ka}$ (Figs. 2 and 3). During these periods, the SKR-FIT indicates median temperatures $3.6 \pm 1.4^{\circ} \mathrm{C}$ higher than modernday, with temperatures up to $4.3 \pm 1.4^{\circ} \mathrm{C}$ higher (Figs. 2 and 3 ). This is significantly higher than lower elevation $(<1000 \mathrm{~m}$ a.s.l.) pollenbased temperature reconstructions of $0-2{ }^{\circ} \mathrm{C}$ above modern-day ${ }^{2,19}$. This contrasting temperature difference between pollen-based reconstructions and the SKR-FIT could be due to pollen records corresponding to either summer (July) or winter (January) temperatures $^{2}$, although pollen records that record mean annual temperatures ${ }^{19}$ also show similar low-temperature anomalies during the early LIG. Differentiating climate estimations between records could also account for the temperature difference, with pollen-inferred temperature reconstructions relying on the use of vegetation-climate transfer functions of key indicator taxon or statistical models linking climate variables and vegetation distribution ${ }^{20}$. Additionally, it is always of concern if pollen-inferred temperature fluctuations during the LIG are reliably constrained in time, which rely solely on biostratigraphy without radiometric age control. If the pollen records provide reliable paleotemperature estimates, then the difference in temperature may instead be a result of elevation, rather than proxy biases. While no high-elevation pollen-based temperature reconstructions exist in Europe for the LIG to directly compare a possible elevation dependence between records, the high-elevation Cesare Battisti Cave in the northern Italian $\mathrm{Alps}^{5}$ (1930 m a.s.l., Fig. 1) agrees within uncertainty with the SKR-FIT record. Temperature reconstructions from this cave record an increase of $4.3 \pm$ $1.6^{\circ} \mathrm{C}$ relative to $1961-1990$, with the high-temperature increase, interpreted as a result of elevation-dependent warming, meaning high-altitude sites react more sensitively to warming than lowelevation sites ${ }^{5}$. The possible significant increase in temperature during the LIG in the European Alps compared to modern-day is consistent with Arctic regions, which show a similarly pronounced warming of $4-5{ }^{\circ} \mathrm{C}$ during the $\mathrm{LIG}^{21}$. The early LIG thermal maximum was interrupted by a cooling event between $125.8 \pm 0.5$ and $124.6 \pm 1.0 \mathrm{ka}$. The SKR-FIT record indicates a $1.9 \pm 1.4^{\circ} \mathrm{C}$ decrease centered at $125.5 \pm 0.5 \mathrm{ka}$ (Figs. 2 and 3) with a second, less pronounced cooling step centered at $124.7 \pm 0.9 \mathrm{ka}$. While evidence for this cold event among archives of sufficient resolution in Europe is still ambiguous, sites in the North Atlantic ${ }^{7,22-24}$ record this cold event prominently, possibly equivalent to cold event $\mathrm{C}^{2} 7^{7}$. It has been suggested that the North Atlantic Deep Water (NADW) ventilation could have become unstable during the early LIG, due to melting from residual ice masses from the penultimate glaciation, or from hydrologic changes related to warming and freshening of the ocean $^{23}$. While it remains unclear where the residual ice may have melted to cause a reduction in NADW, the evidence is increasingly pointing towards the Greenland Ice Sheet or residual ice from the Laurentide Ice Sheet ${ }^{7,22-25}$. Pronounced decreases in N. pachyderma (s.) $\delta^{18} \mathrm{O}$ and bottom-water $\delta^{13} \mathrm{C}$, interpreted as cooling signals, are identified along east Greenland and southwest Greenland margins, respectively, between $\sim 124$ and $126 \mathrm{ka}^{22,23}$ (Figs. 1 and 3). Sea-surface temperatures (SST) also markedly decrease during this interval ${ }^{24}$ (Fig. 3). Additionally, deposition of ice-rafted 


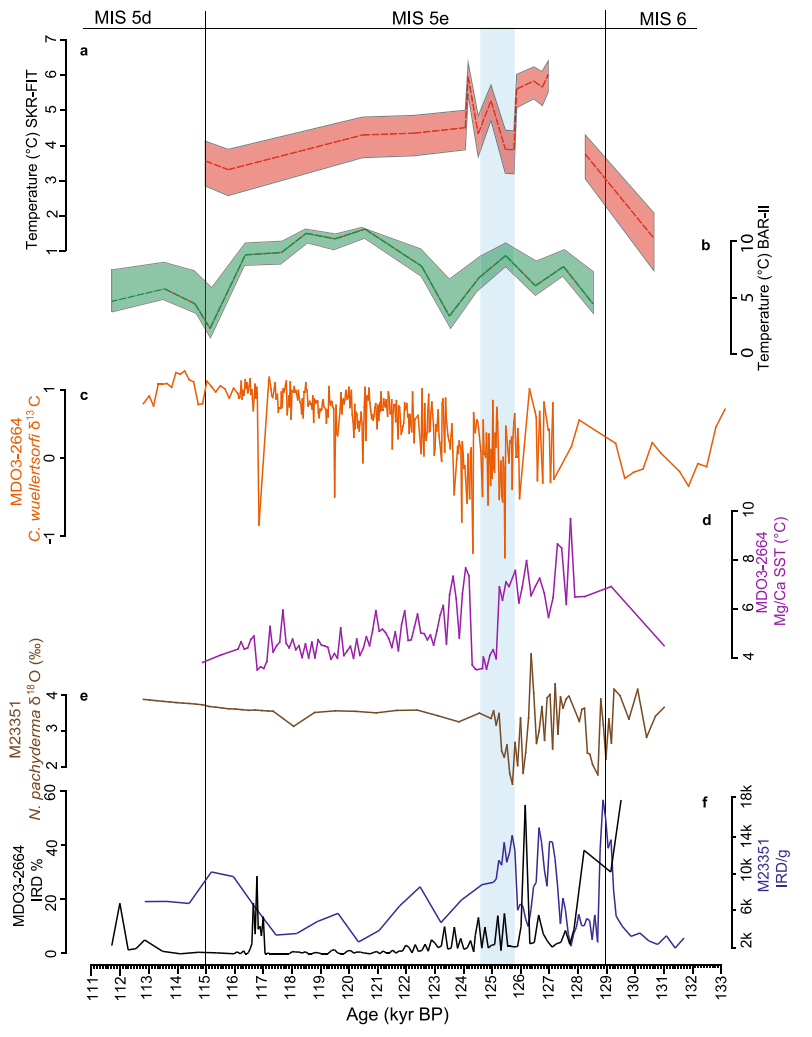

Fig. 3 Schrattenkarst speleothem proxy data compared with other proxy records. a Fluid inclusion temperatures from Schrattenkarst record (this study); $\mathbf{b}$ fluid inclusion temperatures from Baradla Cave ${ }^{26} ; \mathbf{c}, \mathbf{d} \delta^{13} \mathrm{C}$ of $\mathrm{C}$. wuellerstorfi and $\mathrm{Mg} / \mathrm{Ca}$ SST from core MDO3-266423,24; e $\delta^{18} \mathrm{O}$ of $\mathrm{N}$. pachyderma (s.) from core M2335122; f Ice-rafted debris (IRD) from core M23351 (blue) and MD03-2664 (black) ${ }^{23,24}$. Blue shaded region shows cooling interval indicated by the SKR-FIT record. Age uncertainties of marine records $22-24$ are on the order of several thousand years, while the age uncertainty for the Baradla Cave record averages 864 years $^{26}$.

debris (IRD) along the margins of both east and southwest Greenland indicates that iceberg discharge persisted during the early LIG, and was possibly associated with meltwater events 22,24 (Figs. 1 and 3). Further, a prominent red-colored IRD layer, remarkably similar to a red-colored IRD layer deposited during the $8.2 \mathrm{ka}$ BP event, was identified in the Hudson Strait and is associated with the final collapse, and outburst flood, of the Laurentide Ice Sheet ${ }^{25}$. The red layer in MD03-2664 was assigned an age of 124.2-124.7 $\mathrm{ka}^{23}$. Terrestrial evidence of a cold event associated with C27 is ambiguous. The most convincing evidence of cooling was reported from Sokli in northern Finland, where pollen extracted from a sedimentary sequence indicate summer cooling of $\sim 2{ }^{\circ} \mathrm{C}$, which was linked to meltwater pulses into the North Atlantic $^{6}$ (Fig. 1). However, this cooling event is largely unconstrained in time, with the event possibly being related to cold event C28, a hypothesized meltwater event during the early LIG dated to $\sim 128.5 \mathrm{ka}^{7}$. A cooling signal during the early LIG was also identified in a speleothem record from Baradla Cave in Hungary between 127 and $123 \mathrm{ka}^{26}$ (Figs. 1 and 3). However, due to low sample resolution in this interval, correlation to a specific event is unconstrained. Therefore, the low temperatures between $125.8 \pm 0.5$ and $124.6 \pm 1.0$ $\mathrm{ka}$ in the SKR-FIT record are the first well-constrained evidence of a cooling associated with cold event C27 in central Europe. This implies that the impact of $\mathrm{C} 27$ was much more widespread than previously thought, with the event possibly being comparable in magnitude to the $8.2 \mathrm{ka} \mathrm{BP}$ event ${ }^{23}$, which resulted in a $1.7^{\circ} \mathrm{C}$ mean annual air temperature decrease in central Europe ${ }^{27}$. After 124.1 \pm
$0.5 \mathrm{ka}$, the SKR-FIT record suggests gradually decreasing temperatures for the remainder of the record (Figs. 2 and 3). However, temperatures remained 0.5 to $1.8 \pm 0.8^{\circ} \mathrm{C}$ above modern-day temperatures, even during the glacial inception between 122 and 115 $\mathrm{ka}^{28}$. Warm temperatures towards the end of the LIG are consistent with pollen and SST data from core MD95-2042 off southern Portugal which show persistent Eurosiberian and Mediterranean plant species, as well as warm SST's well into MIS $5 \mathrm{~d}^{29,30}$ (Fig. 1). It has been proposed, based on proxy and modeling studies ${ }^{31-35}$, that strengthened NADW ventilation during late MIS $5 \mathrm{e}$ resulted in continued tropical heat transport into the North Atlantic. While the higher-than-modern temperatures revealed by our record support the interpretation of continued heat transport into the North Atlantic during late MIS 5e, cooling conditions between $124.2 \pm 0.5$ and $115.8 \pm 0.4$ ka reveal a gradually deteriorating climate.

Our new quantitative data document exceptionally warm conditions during the LIG in the Alps, as well as a prominent climate reversal, when atmospheric greenhouse gas concentrations were comparable to pre-industrial values of the late Holocene. Although these two warm periods cannot be directly compared because of different orbital settings, the high temperatures and the mounting evidence of unstable nature of the LIG are alarming in the context of future anthropogenic greenhouse projections. In particular, our results suggest that higher elevation sites may amplify warming compared to lower elevation sites. This may imply accelerated warming at higher elevations with increasing greenhouse gases. Additionally, The SKR-FIT record provides compelling evidence that increasing warmth will likely be associated with future climate instability in Europe, which may be linked to a reduction in NADW formation from accelerated melting of the Greenland Ice Sheet.

\section{Methods}

Speleothems M37-1-16A, M37-1-16C, M37-1-23A, and M6-73-3 were cut in half and polished, with total lengths measured at 884, 130.5, 220, and $306 \mathrm{~mm}$, respectively. The base of the speleothems begins at $0 \mathrm{~mm}$. Hendy tests were performed at ten different locations at $21,75,84,190,268,450,500,625,750$, and $850 \mathrm{~mm}$ in the long speleothem (M37-1-16A) to test for isotope equilibrium fractionation (Supplementary Data 3). Fabric texture was identified visually, and shows consistent fabric throughout the speleothems, except at the prominent hiatuses.

U-Th ages. A total of 38 powdered calcite samples were manually drilled for U-Th dating under a laminar flow hood; 24 from M37-1-16A, 5 from M37-1-16C, 4 from M37-1-23A, and 5 from M6-73-3 (Supplementary Fig. 2 and Supplementary Data 1). U-Th samples were processed at the University of Minnesota Trace Metal Isotope Geochemistry Lab and analyzed using a ThermoFisher Neptune Plus multi-collector inductively coupled plasma mass spectrometer equipped with an Aridus desolvation nebulizer, following the method of Shen et al. ${ }^{36,37}$. Ages are reported with $2 \sigma$ errors in years before present, i.e., before the year 1950 A.D. A time-depth model was created in OxCal 4.3 using the Bayesian approach ${ }^{38,39}$. The duration of the hiatuses at 78 and $225 \mathrm{~mm}$ in M37-1-16A, and at $45 \mathrm{~mm}$ in M37-1$16 \mathrm{C}$, was estimated using the time-depth model (Supplementary Fig. 3).

Stable isotopes. A total of 2905 stable isotope locations were drilled using a Merchantek micromill (Supplementary Data 3). In M37-1-16A, samples were drilled every $0.25 \mathrm{~mm}$ from 0 to $78 \mathrm{~mm}$, and every $0.5 \mathrm{~mm}$ from 78 to $884 \mathrm{~mm}$, with a temporal resolution of $\sim 5-10$ years. Samples in M37-1-16C were drilled every $0.3 \mathrm{~mm}$, with a resolution of $\sim 5$ years. In M37-1-23A, samples were drilled every $1 \mathrm{~mm}$, with a resolution of $\sim 70$ years. Lastly, in sample M6-73-3, samples were drilled every $0.5 \mathrm{~mm}$, with a resolution of $\sim 14$ years. Stable isotope samples were analyzed at the University of Innsbruck using a ThermoFisher Delta V isotope ratio mass spectrometer equipped with a Gasbench $\mathrm{II}^{40}$. Stable isotopes are reported in per mil relative to Vienna Peedee Belemnite (VPDB). Long-term analytical precision is better than $0.08 \%$ for both $\delta^{13} \mathrm{C}$ and $\delta^{18} \mathrm{O}(1 \sigma)$.

Fluid inclusions. Speleothem fluid inclusion water isotopes were analyzed at the University of Innsbruck using continuous-flow analysis of water via hightemperature reduction on glassy carbon ${ }^{15} . \delta \mathrm{D}_{\mathrm{f}}$ isotope ratios are given in per mil (\%o) using the standard delta notation and are reported relative to the Vienna Standard Mean Ocean Water (VSMOW). We extracted 28 calcite blocks from 16 
different depths (Supplementary Fig. 2 and Supplementary Data 2), weighing between 2.5 and $3.5 \mathrm{~g}$, from the central growth axis of stalagmites M37-1-16A, M37-1-16C, M6-73-3, and M37-1-23A. Replicates were produced at 8 of the 16 depths (Supplementary Data 2). See Dublyansky and Spötl (2009) ${ }^{15}$ for details on the crushing procedure. The precision of replicate measurements of our in-house calcite standard is typically $1.5 \%$ for $\delta \mathrm{D}_{\mathrm{fi}}$ for water amounts between 0.1 and $1 \mu \mathrm{L}$. Because crushing of our calcite samples released up to $0.86 \mu \mathrm{L}$ of water (mean $0.25 \mu \mathrm{L}$ ), the precision of $1.5 \%$ for $\delta \mathrm{D}_{\mathrm{fi}}$ was found to be adequate for this study. Temporal resolution varied between several hundred to several thousand years. The paleotemperature record of stalagmites M37-1-16A, M37-1-16C, M6-73-3, and M37-1-23A was reconstructed based on the modern-day regional water isotope-temperature relationship ${ }^{41}$. We assumed that the lapse rate was the same for the LIG, and used $\delta^{18} \mathrm{O}$ values of modern precipitation and corresponding temperatures from the Global Network for Isotopes in Precipitation (GNIP) station at Grimsel Pass. This station was selected as it is the closest station $(\sim 24 \mathrm{~km})$, with similar elevation ( $253 \mathrm{~m}$ elevation difference), to Schrattenkarst. We opted not to incorporate paleotemperatures based on equations from ${ }^{5,42}$, as they show a low correlation between calcite $\delta^{18} \mathrm{O}$ and the SKR-FIT record (Supplementary Fig. 4). We would expect some degree of correlation between $\delta^{18} \mathrm{O}$ and the SKR-FIT record if we assume fractionation effects are minor, given that they are both derived from precipitation. Furthermore, the reconstruction based on the modern-day regional water isotope-temperature relationship shows temperatures above $0{ }^{\circ} \mathrm{C}$ for the duration of the record, necessary for speleothem deposition. Equations from refs. ${ }^{5,42}$, on the other hand, show temperatures well below $0^{\circ} \mathrm{C}$, which are unrealistic for speleothem deposition. Only $\delta \mathrm{D}_{\mathrm{fi}}$ values were used for calculating paleotemperatures for the following reasons: post-depositional processes can alter the original $\delta^{18} \mathrm{O}_{\mathrm{fi}}$ in fluid inclusion water and thus limit the use of $\delta^{18} \mathrm{O}_{\mathrm{fi}}$ for paleotemperature calculations ${ }^{43}$. And, $\delta \mathrm{D}_{\mathrm{fi}}$ is not affected by isotopic fractionation during calcite precipitation and remains unaltered as there is no hydrogen source once the water is entrapped in the calcite matrix. To determine $\delta \mathrm{D}$ for Grimsel Pass, we obtained $\delta^{18} \mathrm{O}$ measurements from the GNIP dataset and converted to $\delta \mathrm{D}$, as the GNIP dataset is missing several years of $\delta \mathrm{D}$ measurements. The $\delta^{18} \mathrm{O} /$ annual air temperature slope was determined from the Grimsel Pass GNIP station for the period spanning 1971-1990. This time period was selected in order to limit Anthropocene warming effects, which generally rises sharply after 1990. Because it is unclear which transfer function might be appropriate for the LIG, we evaluate a range of possible transfer function scenarios for the LIG, between 0.6 and $0.7 \% /{ }^{\circ} \mathrm{C}$, which represents the error of the Grimsel Pass transfer function. Next, a $\delta \mathrm{D} / \mathrm{T}$ transfer function $\left(5.2 \% / /{ }^{\circ} \mathrm{C}\right.$ for Grimsel Pass) was determined by converting the annual air temperature slope by a factor of eight. We used the global meteoric water line relationship $\left(\delta \mathrm{D}=8 \delta^{18} \mathrm{O}+10\right)$ to convert $\delta \mathrm{D}_{\mathrm{fi}}$ to $\delta^{18} \mathrm{O}_{\text {calculated }}$ (Supplementary Data 2). Finally, we converted $\delta^{18} \mathrm{O}_{\text {calculated }}$ to temperature by incorporating the $\delta^{18} \mathrm{O} /$ annual air temperature slope of $0.65 \pm 0.05 \% /{ }^{\circ} \mathrm{C}$ (Supplementary Data 2 and Supplementary Fig. 5). The mean annual air temperature (MAAT) at Schrattenkarst between 1971 and 1990 is $2.1^{\circ} \mathrm{C}$ based on linear regression of the regional lapse rate of $0.51^{\circ} \mathrm{C} / 100 \mathrm{~m}$ from Grimsel Pass (Supplementary Fig. 6). Further, $\delta \mathrm{D}$ was corrected for the ice volume effect of $-0.064 \%$ per meter of sea level rise ${ }^{37}$, with sea level during the LIG approximated using the mean global sea level reconstructed from core KL11 from the Red Sea ${ }^{44}$. The modern uplift rates in the study area are $\sim 0.5 \mathrm{~mm} / \mathrm{yr}^{45}$, which translates into $\sim 60 \mathrm{~m}$ of uplift since the LIG. Rock uplift rates due to the melting of the Last Glacial Maximum ice cap and concomitant erosion contribute significantly to the modern vertical displacement rates in the Alps ${ }^{46}$. We, therefore, regard the $\sim 60 \mathrm{~m}$ of uplift since the LGM as a likely maximum value. Based on the regional lapse rate, this equates to a temperature decrease of $\sim 0.3^{\circ} \mathrm{C}$ since the LIG. To account for this uplift component, we decreased the SKR-FIT values by $0.3{ }^{\circ} \mathrm{C}$ (Supplementary Data 2). We do not account for changes in the seasonality of precipitation nor changes in atmospheric circulation patterns across Termination II and into the LIG. Fluid inclusion data were also obtained from a Holocene stalagmite from Neotektonik Cave (M6-1-20, Supplementary Data 2) to test whether a subrecent speleothem from this cave yields values comparable to modern temperatures. Samples were analyzed at $2.8 \pm 0.2 \mathrm{ka}$ and $4.4 \pm 0.3 \mathrm{ka}$ (Supplementary Data 2). Due to lack of water, we were unable to obtain data from younger layers of this stalagmite. The Holocene fluid inclusions yielded an average temperature of $2.0 \pm 1.4^{\circ} \mathrm{C}$, well within the error of the modern MAAT of $2.1^{\circ} \mathrm{C}$. Further, temperatures in central Europe are reported to be within $\pm 1{ }^{\circ} \mathrm{C}$ of the mean temperature of the twentieth century at $2.5 \mathrm{ka}^{47}$, suggesting that our subrecent fluid inclusion temperature provides a strong anchor point to LIG temperatures. Uncertainties reflect isotope measurement errors, $\delta^{18} \mathrm{O} /$ annual air temperature slope error, and one standard deviation of repeated measurements. The uncertainties are applied through all steps of the paleotemperature calculation. Further, uncertainties are propagated between SKR-FIT sampling locations.

\section{Data availability}

All data are available on Pangaea.

Received: 18 June 2020; Accepted: 17 November 2020; Published online: 08 December 2020

\section{References}

1. Otto-Bliesner, B. L. et al. How warm was the last interglacial? New model-data comparisons. Philos. Trans. R. Soc. A. 371, https://doi.org/10.1098/ rsta.2013.0097 (2013).

2. Kaspar, F., Kühl, N., Cubasch, U. \& Litt, T. A model-data comparison of European temperatures in the Eemian interglacial. Geophys. Res. Lett. 32, L11703 (2005)

3. Lunt, D. J. et al. A multi-model assessment of last interglacial temperatures. Clim. Past 9, 699-717 (2013).

4. Fischer, H. et al. Palaeoclimate constraints on the impact of $2{ }^{\circ} \mathrm{C}$ anthropogenic warming and beyond. Nat. Geosci. 11, 474-485 (2018).

5. Johnston, V. E. et al. Evidence of thermophilisation and elevation-dependent warming during the Last Interglacial in the Italian Alps. Sci. Rep. 8, 1-11 (2018).

6. Salonen, J. S. et al. Abrupt high-latitude climate events and decoupled seasonal trends during the Eemian. Nat. Commun. 9, 2851 (2018).

7. Tzedakis, P. C. et al. Enhanced climate instability in the North Atlantic and southern Europe during the Last Interglacial. Nat. Comm. 9, 4235 (2018).

8. Kühl, N. \& Litt, T. Quantitative time series reconstruction of Eemian temperature at three European sites using pollen data. Veg. Hist. Archaeobot. 12, 205-214 (2003)

9. Plikk, A. et al. Chironomid-based temperature reconstruction for the Eemian Interglacial (MIS 5e) at Sokli, northeast Finland. J. Paleolimnol. 61, 355-371 (2019).

10. Van Breukelen, M. R., Vonhof, H. B., Hellstrom, J. C., Wester, W. C. G. \& Kroon, D. Fossil dripwater in stalagmites reveals Holocene temperature and rainfall variation in Amazonia. Earth Planet. Sci. Lett. 275, 54-60 (2008).

11. Wainer, K. et al. Speleothem record of the last $180 \mathrm{ka}$ in Villars cave (SW France): Investigation of a large $\delta 180$ shift between MIS6 and MIS5. Quat. Sci. Rev. 30, 130-146 (2011).

12. Meckler, A. N. et al. Glacial-interglacial temperature change in the tropical West Pacific: a comparison of stalagmite-based paleo-thermometers. Quat. Sci. Rev. 127, 90-116 (2015).

13. Affolter, S. et al. Central Europe temperature constrained by speleothem fluid inclusion water isotopes over the past 14,000 years. Sci. Adv. 5, eaav3809 (2019).

14. Vonhof, H. B. et al. A continuous-flow crushing device for on-line $\delta^{2} \mathrm{H}$ analysis of fluid inclusion water in speleothems. Rapid Commun. Mass Spectrom. 20, 2553-2558 (2006).

15. Dublyansky, Y. V. \& Spötl, C. Hydrogen and oxygen isotopes of water from inclusions in minerals: design of a new crushing system and on-line continuous-flow isotope ratio mass spectrometric analysis. Rapid Commun. Mass Spectrom. 23, 2605-2613 (2009).

16. Trüssel, M. Arbeitsbericht NAB 14-73, Nachweis von fünf Karstniveaus in Obwalden und Nidwalden mit ersten radiometrischen U/Th-Datierungen von Stalagmiten in den beiden jüngsten fossilen Karstniveaus. Nationale Genossenschaft für die Lagerung radioaktiver Abfälle, Wettingen. https://www. nagra.ch/data/documents/database/dokumente/\$default/Default\%20Folder/ Publikationen/NABs\%202004\%20-\%202015/d_nab14-073.pdf (2014).

17. Gisler, C. et al. Erläuterungen zum Geologischer Atlas der Schweiz 1:25000, 1210 Innertkirchen (Federal Office of Topography swisstopo, Wabern, 2020).

18. Trüssel, M. Vom Fuchsloch zur Schrattenhöhle. Obwaldner Karst- und Höhlenforschung 2003 bis 2012. Vols. 4-5 (Alpnach, 2013).

19. Brewer, S., Guiot, J., Sánchez-Goñi, M. F. \& Klotz, S. The climate in Europe during the Eemian: a multi-method approach using pollen data. Quat. Sci. Rev. 27, 2303-2315 (2008).

20. Brewer, S., Guiot, J., \& Barboni, D. in Encyclopedia of Quaternary Science Vol. 4 (ed. Elias, S. A.) 2498-2510 (Elsevier, 2007)

21. CAPE-Last Interglacial Project Members. Last Interglacial Arctic warmth confirms polar amplification of climate change. Quat. Sci. Rev. 25, 1383-1400 (2006).

22. Zhuravleva, A., Bauch, H. A. \& Van Nieuwenhove, N. Last Interglacial (MIS5e) hydrographic shifts linked to meltwater discharges from the East Greenland margin. Quat. Sci. Rev. 164, 95-109 (2017).

23. Galaasen, E. V. et al. Rapid reductions in North Atlantic Deep Water during the peak of the last interglacial period. Science 343, 1129-1132 (2014).

24. Irvall, N. et al. Evidence for regional cooling, frontal advances, and East Greenland Ice Sheet changes during the demise of the last interglacial. Quat. Sci. Rev. 150, 184-199 (2016).

25. Nicholl, J. A. et al. A Laurentide outburst flooding event during the last interglacial period. Nat. Geosci. 5, 901-904 (2012).

26. Demény, A. et al. Stable isotope compositions of speleothems from the last interglacial-spatial patterns of climate fluctuations in Europe. Quat. Sci. Rev. 161, 68-80 (2017).

27. Von Grafenstein, U., Erlenkeuser, H., Müller, J., Jouzel, J. \& Johnsen, S. The cold event 8200 years ago documented in oxygen isotope records of precipitation in Europe and Greenland. Clim. Dyn. 14, 73-81 (1998).

28. North Greenland Ice Core Project members. High resolution record of Northern Hemisphere climate extending into the last interglacial period. Nature 431, 147-151 (2004) 
29. Sánchez Goñi, M. F., Eynaud, F., Turon, J. L. \& Shackleton, N. J. High resolution palynological record off the Iberian margin: direct land-sea correlation for the Last Interglacial complex. Earth Planet. Sci. Lett. 171, 123-137 (1999).

30. Shackleton, N. J., Sánchez Goñi, M. F., Pailler, D. \& Lancelot, Y. Marine isotope substage $5 \mathrm{e}$ and the Eemian interglacial. Glob. Planet. Change 36, 151-155 (2003).

31. Mokeddem, Z., McManus, J. F. \& Oppo, D. W. Oceanographic dynamics and the end of the last interglacial in the subpolar North Atlantic. Proc. Natl. Acad. Sci. USA 111, 11263-11268 (2014).

32. McManus, J. F., Oppo, D. W., Keigwin, L. D., Cullen, J. L. \& Bond, G. C. Thermohaline circulation and prolonged interglacial warmth in the north Atlantic. Quat. Res. 58, 17-21 (2002).

33. Risebrobakken, B. et al. Inception of the Northern European ice sheet due to contrasting ocean and insolation forcing. Quat. Res. 67, 128-135 (2007).

34. Born, A., Nisancioglu, K. H. \& Braconnot, P. Sea ice induced changes in ocean circulation during the Eemian. Clim. Dyn. 35, 1361-1371 (2010).

35. Born, A., Nisancioglu, K. H. \& Risebrobakken, B. Late Eemian warming in the Nordic Seas as seen in proxy data and climate models. Paleoceanography 26, pa2207 (2011).

36. Shen, C. C. et al. High-precision and high-resolution carbonate ${ }^{230} \mathrm{Th}$ dating by MC-ICP-MS with SEM protocols. Geochim. Cosmochim. Acta 99, 71-86 (2012).

37. Duplessy, J. C., Roche, D. M. \& Kageyama, M. The deep ocean during the last interglacial period. Science 316, 89-91 (2007).

38. Bronk Ramsey, C. Deposition models for chronological records. Quat. Sci. Rev. 27, 42-60 (2008).

39. Bronk Ramsey, C. \& Lee, S. Recent and planned developments of the program OxCal. Radiocarbon 55, 720-730 (2013).

40. Spötl, C. Long-term performance of the Gasbench isotope ratio mass spectrometry system for the stable isotope analysis of carbonate microsamples. Rapid Commun. Mass Spectrom. 25, 1683-1685 (2011).

41. Rozanski, K., Araguas-Araguas, L. \& Gonfiantini, R. Relation between longterm trends of oxygen-18 isotope composition of precipitation and climate. Science 258, 981-985 (1992).

42. Tremaine, D. M., Froelich, P. N. \& Wang, Y. Speleothem calcite farmed in situ: Modern calibration of $\delta^{18} \mathrm{O}$ and $\delta^{13} \mathrm{C}$ paleoclimate proxies in a continuously-monitored natural cave system. Geochim. Cosmochim. Acta 75, 4929-4950 (2011).

43. McDermott, F. Palaeo-climate reconstruction from stable isotope variations in speleothems: a review. Quat. Sci. Rev. 23, 901-918 (2004).

44. Rohling, E. J. et al. Asynchronous Antarctic and Greenland ice-volume contributions to the last interglacial sea-level highstand. Nat. Commun. 10, 1-9 (2019)

45. Nagra. Vorschlag weiter zu untersuchender geologischer Standortgebiete mit zugehörigen Standortarealen für die Oberflächenanlage. Nagra Tech. Ber. NTB 14-01. https://www.nagra.ch/display.cfm/id/102088/disp_type/display/ filename/d_ntb14-01\%20Textband.pdf (2014).

46. Sternai, P. et al. Present-day uplift of the European Alps: Evaluating mechanisms and models of their relative contributions. Earth-Sci. Rev. 190 590-604 (2019).
47. Büntgen, U. et al. 2500 years of European climate variability and human susceptibility. Science 331, 578-582 (2011).

\section{Acknowledgements}

This study was funded by the Austrian Science Fund (FWF) grant P300040 to C.S. We thank Yuri Dublyansky and Marlene Steck for their help in the stable isotope laboratory, and Andrea Schröder-Ritzrau for providing part of sample M6-1-20, and Stacy Carolin for helpful comments on an earlier version of the manuscript. I also thank Jessica Honkonen for her never-ending support.

\section{Author contributions}

P.S.W. performed the majority of analytical work and wrote the manuscript. M.T. oversaw fieldwork, C.H. assisted with analytical work and provided manuscript feedback, L.R.E. assisted with U-Th measurements, C.S. designed this research project, participated in fieldwork, and provided manuscript feedback.

\section{Competing interests}

The authors declare no competing interests.

\section{Additional information}

Supplementary information is available for this paper at https://doi.org/10.1038/s43247020-00063-w.

Correspondence and requests for materials should be addressed to P.S.W.

Peer review information Primary handling editor: Joe Aslin.

Reprints and permission information is available at http://www.nature.com/reprints

Publisher's note Springer Nature remains neutral with regard to jurisdictional claims in published maps and institutional affiliations.

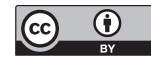

Open Access This article is licensed under a Creative Commons Attribution 4.0 International License, which permits use, sharing, adaptation, distribution and reproduction in any medium or format, as long as you give appropriate credit to the original author(s) and the source, provide a link to the Creative Commons license, and indicate if changes were made. The images or other third party material in this article are included in the article's Creative Commons license, unless indicated otherwise in a credit line to the material. If material is not included in the article's Creative Commons license and your intended use is not permitted by statutory regulation or exceeds the permitted use, you will need to obtain permission directly from the copyright holder. To view a copy of this license, visit http://creativecommons.org/ licenses/by/4.0/.

(C) The Author(s) 2020, corrected publication 2022 